\title{
International Tax Planning Methodology and Best Practices of Russian Economy Deoffshorization
}

\author{
Inna Vladimirovna Lipatova ${ }^{1} \&$ Lyudmila Vladimirovna Polezharova $^{1}$ \\ ${ }^{1}$ Financial University under the Government of the Russian Federation (Financial University), Russian \\ Federation \\ Correspondence: Lyudmila Vladimirovna Polezharova, Leningradsky Avenue, 49, Moscow, 125468, Russian \\ Federation. E-mail: lpolezharova@mail.ru
}

\author{
Received: February 29, 2015 Accepted: May 17, 2015 Online Published: July 30, 2015 \\ doi:10.5539/ass.v11n19p316 URL: http://dx.doi.org/10.5539/ass.v11n19p316
}

\begin{abstract}
The purpose of the article is identification of the international tax planning methodology and methods of deoffshorization of the modern Russian economy in order to determine the direction of their improvement, taking into account the need to ensure the economic security of Russia. The article defines the tax planning objectives, content and technology. The article defines a place of the tax planning in the system of tax management. There is a definition of concept and content of the international tax planning as the tax planning method. We have analyzed the different techniques of the international tax planning, most commonly used by the Russian organizations, including the method of offshore. Using the analysis of current statistical data, we have assessed the impact of the international tax planning with the use of low-tax jurisdictions on the economies of capital donor country. There is an estimation of the Russian economy offshorization extent and effects in terms of the economic security. We have analyzed and characterized the tax methods of the Russian economy deoffshorization. The article provides specific recommendations on improving the new Russian methods of the offshore tax regulation and correction of the international tax planning methods under the new conditions - with respect to the improvement of the Russian CFC rules, the new rules on legal entity residence, and the beneficial owner.
\end{abstract}

Keywords: the international tax planning, the "treaty shopping", the Russian economy deoffshorization, the controlled foreign companies, the beneficial owner, the information exchange, the BEPS plan

\section{Introduction}

The tax planning is carried out in order to optimize tax payments (Babanin \& Voronina, 2006), and individual taxes may be lowered for social support of the population and small businesses, and some taxes may be raised in connection with the current economic situation in the country.

The tax planning technology consists of the following procedures (Beskarovayny, 2006): analysis of the legal and regulatory information on the operations carried out; assessment of tax obligations imposed on the organization in transactions; optimization of operations including the tax liabilities; preparation of necessary documents and their background for the operations exercising and support; calculations and tax payment if necessary.

The tax planning involves "gating" the behavior of the taxpayer under elected favorable tax regime and therefore, in many cases, calls for business form or even content change. First of all, such changes shall deal with the features, which focus the tax laws in determining the tax liabilities of individuals and legal entities.

Firstly, it is the taxation object; these are transaction, property, income. Changing this object to the extent according to the circumstances, the taxpayer can choose a more advantageous tax mode and type.

Second, you can replace the taxation subject, i.e. the taxpayer. For instance, the organization may change its legal form from LTD to JSC. Changing the taxpayer subject may also be provided as a result of the reorganization of the legal entity.

Third, you can go from one tax jurisdiction to another. So the person, who retrieves his/her core business in any country, will be a non-resident in relation to the tax jurisdiction of the country, which allows the specified person to choose the taxation at-source mode. 
Fourth, you can change the circumstances surrounding a particular taxable activity. In particular, it is possible when using various types of deductions, discounts, write-offs and other benefits, allowed in the determination of taxable income in order to calculate income taxes (Lipatova, 2011).

The tax planning may be considered as one of the main functions of the financial management. Figure 1 defines a place of the tax planning in the tax management system.

The tax planning as an integral part of the tax management helps to reduce the absolute number of payments in the budget by using the difference in the taxable bases and tax rates, tax exemptions stipulated by law, and similar factors, which are independent of the organization and are set by the state.

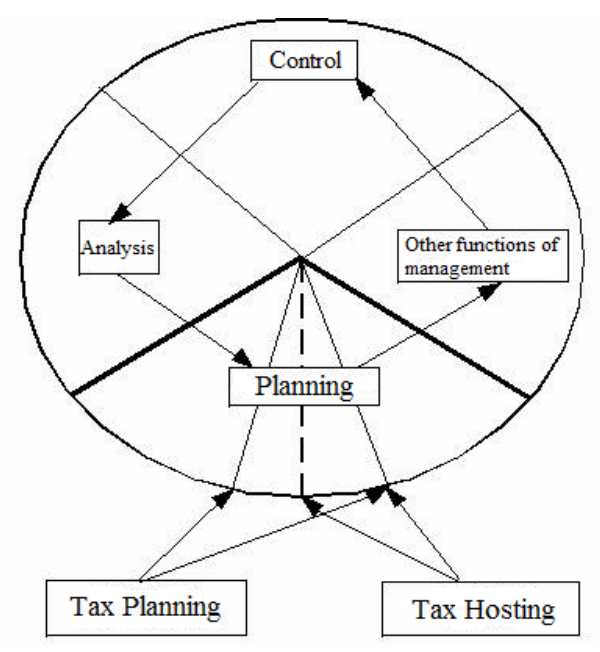

Figure 1. Place of the tax planning in the tax management system

Tax planning, as well as the tax circumvention, aims to legitimate tax reduction. For the tax planning can be distinguished from the tax circumvention, the following criteria are used:

- Manipulation of the categories clearly known when the planned result can be determined with some degree of possibility;

- As a special case, the tax planning may include elements of the tax circumvention and evasion.

\section{Methods}

\subsection{International Tax Planning as a Method of the Tax Optimization}

In the present conditions of the practice, we define two main methods of the tax planning: the domestic tax planning, and the tax planning beyond national borders. Domestically, the tax environment and tax risks for all taxpayers roughly equal. In this case, the business decision-making is primarily guided by economic and political conditions. In the case of the international tax planning, when making business decisions, on the contrary, the economic and political circumstances do not play a significant role. Opposed to the national tax planning, the international tax planning is based on differences in taxation taking place in different countries.

In the formation of its operations, the international business shall take into account the state's level of tax appeal, where he or she will operate. Moreover, in certain cases, namely tax considerations play a decisive role in the choice of the business location. Typically, a corporation completely rebuilds its global tax structure basing on conditions in the country.

Thus, international tax planning is the formation of financial and economic activity, where you should choose the best options and methods of economic activity and asset allocation in different jurisdictions, aimed at ensuring the achievement of the occurring tax obligation's lower level.

Any business is trying to find legal ways of the tax planning regardless of the liberal level of the state tax legislation. Legal tax planning is not just a well-delivered accounting and correct reporting of balances, but a legitimate opportunity either not to pay taxes at all, or to reduce them to the minimum amount. 
International tax planning is also a legitimate activity of the company to minimize taxes in the international business, which is implemented on the basis of the correct application of the tax and civil law. Operations beyond the Russian market give the company a clear competitive advantage, including the minimization of taxation and reduced political risk. Due to the proper use of a number of the taxation methods, you can increase the volume of working capital only through the minimization of tax losses (Lipatova, 2011)

\subsubsection{Treaty Shopping}

Familiarity with the tax laws of different jurisdictions, as well as relevant international tax treaties is necessary to build an effective international tax structure of the business.

Many countries have agreements on the tax rules. These rules are mainly to eliminate the possibility of taxing the same income twice, in two countries. Such tax treaties or agreements on avoidance of double taxation are very common as a tool in international relations.

Generally, the tax treaties are concluded between countries with a "normal" level of taxation, and offshore zones, i.e. the countries with zero (or near zero) taxes, have no such treaties. If there is no tax, there is no double taxation. The countries with high taxes are not willing to provide the same one-sided tax breaks for offshore companies. Even if the treaty with a country is concluded, then, as a rule, the offshore companies are explicitly excluded from it.

In addition to bilateral tax treaties, multilateral treaty relations may act. For example, the EU countries apply rules on the avoidance of double taxation on dividends received from subsidiaries to residents of each other (it is applied only to companies that are active since 2015), and therefore, Cyprus after the entry into the EU dramatically expand its international tax activities.

In addition to their direct function, the international tax treaties facilitate interstate commerce and relieve the burden of double taxation, according to their individual provisions, allow to further reducing taxes by targeted modification of the relevant business.

Targeted use of tax treaties to minimize tax payments is called "treaty shopping". It is usually not welcomed by the government. The texts of the agreements or national legislation sometimes include special provisions restricting such economic behavior. Yet in most cases, such use of tax treaties is not forbidden by law.

The Russian Federation inherited the tax treaties with more than twenty countries from the USSR. After the USSR collapse, Russia began active work in the signing of new treaties and renegotiation of previously existing ones. Now, there are more than 70 tax treaties of the Russian Federation, only one of which was signed before the collapse of the Soviet Union (Russia-Japan Agreement).

In the case when there is no tax treaty with a country, our government provides companies with unilateral relief from double taxation, which means that if the Russian company has legally paid taxes abroad, then in the provision of relevant documents, it is accepted to the domestic tax payment offset, i.e. in the Russian Federation. The foreign tax offset is limited by the income tax rate under the tax legislation of Russia (20\%).

\subsubsection{Offshore}

The companies operating in tax-free or low-tax environment may be used for the purposes of the tax reduction. It can be both offshore companies and companies from countries with certain tax benefits. The offshore companies are tax-free or low-tax companies registered in offshore zones. The countries and territories targeted attracting international business by providing it with tax benefits, often a full exemption are so called.

Advantages of offshore are reduced to complete financial privacy; protection of assets; reduction of income tax; protection against inflation; limitation of liability; reduction of management costs; absence of exchange controls; recognition, support and subsidizing by the local government and other local authorities; owners and directors' information are not subject to publicity and remain confidential; availability of banking services and world-class investment management; easy access to major markets in North America and Europe; no international trade tariffs; no limitations on the scope of export/import; no costly bureaucracy. The common offshore zones list does not exist; the control of the offshore zones is conducted by both the International Monetary Fund, and central banks around the world.

Despite the fact that recently arrangements for the international tax planning have become a promising area of financial services, and they are used by almost all participants of foreign economic activity, thus minimizing their tax payments, in the current development period of global economic, the offshore use faces with some difficulties. These difficulties are caused by the desire of a number of developed countries, especially the members of the Organization for Economic Cooperation and Development, to dismantle the existing offshore 
zones. Government agencies of the taxable countries are usually not completely satisfied by their residents' offshore activities aimed at reducing taxes. However, their ability to counter this activity is limited because it is conducted outside their jurisdiction. However, some "anti- offshore" measures are applied in a sufficiently broad scope. The measures against offshore companies are conducted by forming a "black list" of unscrupulous states. The companies from these countries are somehow discriminated, and the residents, who have deals with them, are subject to severe sanctions. These lists are made by both national authorities and international organizations such as the OECD and the FATF. Most developed countries led the struggle against getting profit by their residents in offshore tax-free mode by the so-called legislation on controlled foreign companies and enterprises.

To get information about the offshore, the developed countries enter into agreements with the offshore zones for the tax information exchange. In addition, the offshore jurisdictions are got under appropriate pressure in order to change their laws to increase transparency of the banking system and the corporate structures' actions.

\subsubsection{Dividend Distribution as a Tax Planning Mechanisms}

Increasing efficiency of the foreign companies under the ownership structure, the financing structure, the export and trade structure, the operational structure can lead to the following results:

- Tax costs reduction, which is important in the financial crisis;

- Simplification/acceleration of taxation and foreign exchange controls procedures;

- Release of financial resources;

- Reduction of the tax risks.

Therefore, it is advisable to consider the international tax planning mechanisms leading to these results. At the same time, the following requirements shall be met to reduce the tax risk associated with intra-group transactions:

- The existence of a real economic feasibility of operations (confirmation of a business purpose);

- Confirmation of the companies' activity sufficient level;

- Maintaining the level of market prices for intra-group transactions.

Let's analyze the specific advantages associated with the use of the international tax planning.

According to the Tax Code of the Russian Federation, Chapter 25 "Corporate Profit Tax" and Section 284 "Peculiarities of tax rate of 0 per cent to the tax base determined by the operations of the Russian companies" (the Tax Code of the Russian Federation. 2014), the income received from the Russian organizations are taxed at $13 \%$. At the time, if the entity paying the dividends is foreign, the country of residence which is not included in the list of countries approved by the Russian Ministry of Finance, which provide preferential tax mode and do not require the disclosure of information on financial operations (the offshore zones), the tax rate on dividends is 0 percent. And if the corresponding Russian holding company receives dividends from a company located, for example, in Hungary or Turkey through subholding company in a country, such as Italy or Romania, the effective tax rate is $0 \%$, which is much more attractive than $13 \%$. The tax rate paid to the government in taxes after the tax adjustment is carried out (for example, interests are paid for loans) (see Figure 2).

The effective tax rate on dividends - $0 \%$ (Under certain conditions)
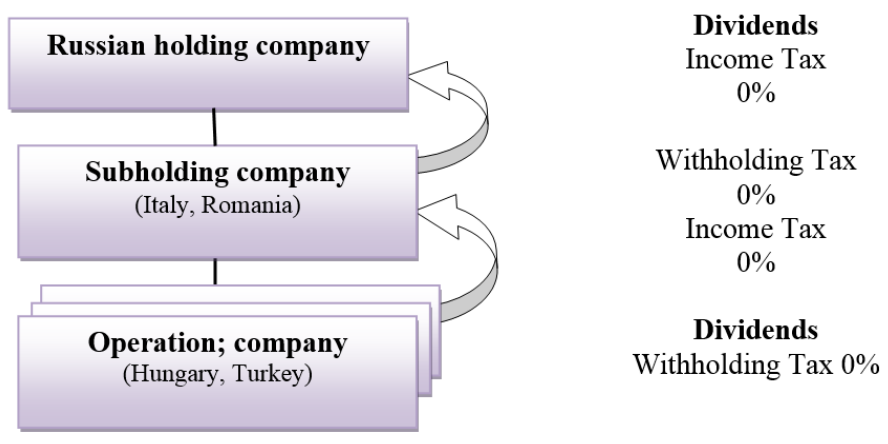

Figure 2. Dividend distribution diagram 


\subsubsection{Tax Optimization Using a Share Seller's Residence Change \& Export Trading Structure}

Under current Russian law, the proceeds from the sale of assets (sale of property rights and funds) are taxed at $20 \%$. At the same time, if there is:

- A transfer of the vendor's effective management location to the jurisdiction of favorable agreements on avoidance of double taxation with the Russian Federation and the local tax laws;

- Receiving of a tax favorable jurisdiction residence certificate on the basis of "effective management location", the taxation of income from the sale of shares: in the Russian Federation is $0 \%$ (by agreement); abroad is $0 \%$ (by law) (see Figure 3).

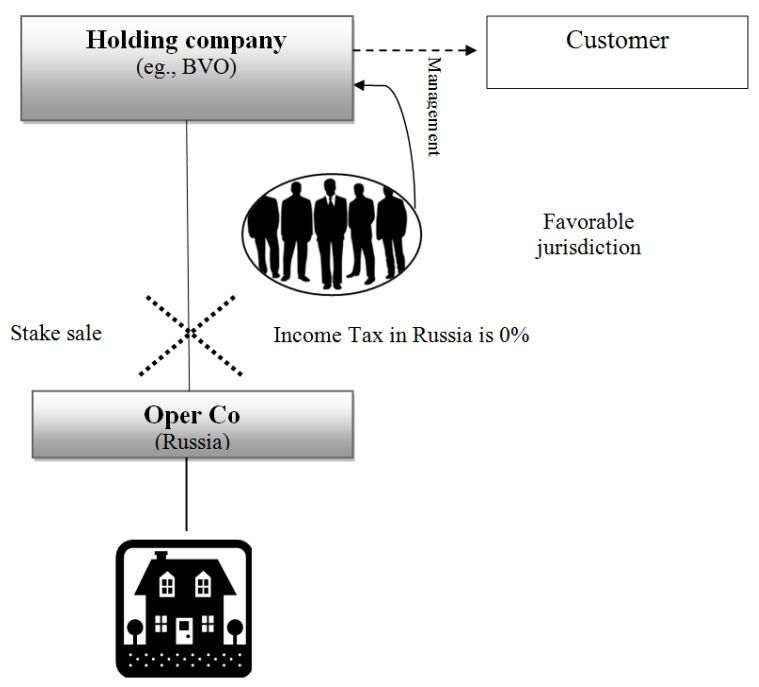

Figure 3. Seller's tax residence change

The following disadvantages arise upon the sale of manufactured products by the Russian production company directly to several foreign customers: the effective income tax rate is $20 \%$, the difficulty of documents collecting for each customer individually, and as a result:

- Risks of non-reimbursement or untimely reimbursement of export VAT;

- Complexity of the transaction certificate.

However, these problems can be solved with the use of the foreign trade company. Using of the foreign trade company provides foreign trading companies with a low level of income taxation, simplification of the export VAT refund and transaction certificate issuing (the documents provision only in respect of the foreign customer) (see Figure 4).

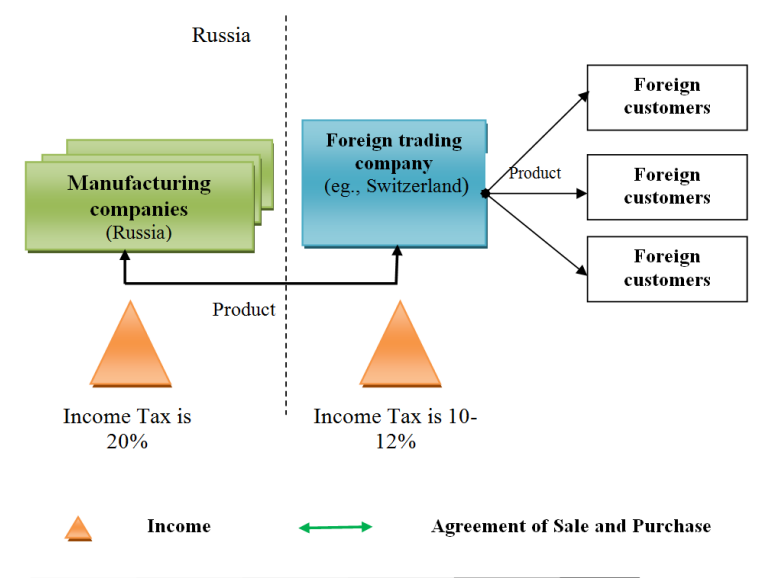

Figure 4. Export Trading Structure with Foreign Trading Company

* For example, it is in the case of NTA in Switzerland, which has a favorable tax status. 


\subsubsection{Tax Optimization Using a Loan with Participation in Profits}

As an example, we consider a loan provided if the finance company is located in a favorable jurisdiction, for example, in Luxembourg. Let's suppose the Russian corporation receives a loan from the Luxembourg Finance Corporation. Then:

- Interests paid by the Russian companies can reduce their taxable income and may be exempt from withholding tax in the Russian Federation;

- Interests received by the financial corporation can be reclassified as dividends under the jurisdiction of its incorporation (e.g. Luxembourg) under specific conditions;

- The dividends may be exempt from tax in the jurisdiction of the financial corporation and in further distribution (depending on the jurisdiction of incorporation of the Holding Company) (see Figure 5).

Thus, at the present stage of development in the context of globalization and internationalization of economic relations, the international tax planning plays an important role in the taxpayers' activity. The sharp intensification of the processes related to the international capital migration calls for the effect consideration and calculation of a large number of different factors and risks, including a variety of tax factors and risks in the determination of the business "geography".

The above international tax planning schemes to reduce the tax burden demonstrate the attractiveness of the mechanism. Consequently, the Russian companies and entrepreneurs should pay special attention to them in order to minimize the tax payments and thus maximize their profits. Until recently, the Russian tax legislation did not almost prevent the widespread use of the international tax planning by the Russian taxpayers (Sec. 34 of the Constitution of the Russian Federation). Therefore, the implementation of these activities has been the significantly effective.

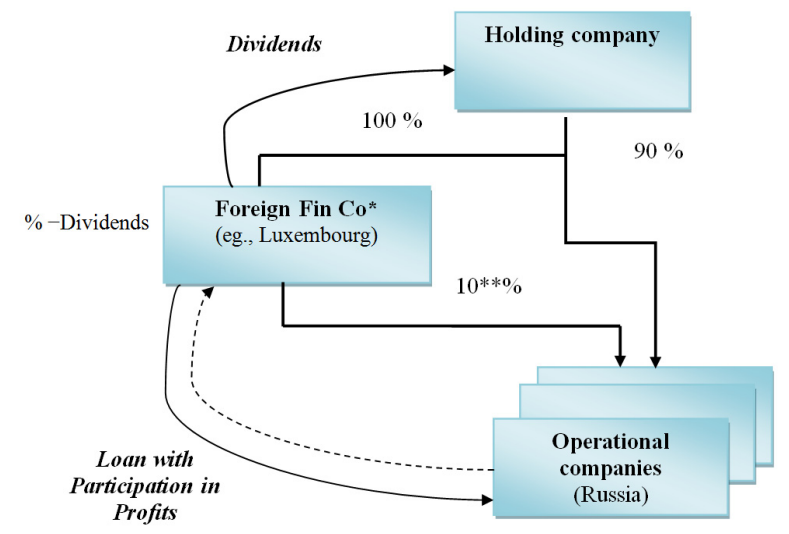

Figure 5. Loan with participation in profits

* The jurisdiction allowing reclassifying the received interests as dividends, for example, Luxembourg.

** The share of participation may not exceed $20 \%$, but shall be sufficient to obtain the exemption from taxation of dividends ("participation exemption").

\subsection{Methods to Counteract the Minimizations of Taxation Based on Low-tax Jurisdictions}

\subsubsection{Offshore Negative Impact Analysis on the Capital Donor Countries' Economy}

According to the retrospective analysis, the practice of international tax planning with the use of low-tax jurisdictions has more than a dozen years, but in recent years, the tendency to confront them have increased. In the current studies, the negative impact mainly highlights that is experienced by the donor offshore countries. Thus, each year many developed and developing countries suffer huge losses due to tax evasion and tax avoidance, which became possible due to offshore companies. This behavior of taxpayers, both organizations and individuals, has a negative impact on law-abiding taxpayers, the state budget, the social spending, as well as government, economic stability, social tranquility. This position was declared repeatedly by international organizations as well as representatives of the particular states. In particular, according to the OECD report of 12 February 2013. Addressing Base Erosion and Profit Shifting, many companies' evasion from taxation using 
offshore instruments has received threatening global economic scale (Addressing Base Erosion and Profit Shifting, 2013).

The donor states are forced to compete with tax havens in order to avoid capital flow. These impacts negatively on other areas of their internal politics, which depend on tax revenue.

Developed countries have already gained some experience in dealing with the negative manifestations of the low-tax jurisdictions, but a final solution has not been found yet. Compared to Europe and the United States, Russia has only recently begun to suffer the problems caused by the excretion of capital, however, as indicated by the statistics, these problems have affected the Russian economy much more than Western countries.

\subsubsection{Russian Economy Offshorization: Extent and Consequences Assessment}

At the present stage of development, the practice of using offshore companies became part of the everyday life of the Russian companies and wealthy individuals. According to the Institute of World Economy and International Relations of the Russian Academy of Sciences, voiced by the Expert Magazine (Obukhova \& Ogorodnikov, 2013), up to $25 \%$ of companies with revenues of more than 30 billion rubles have a parent holding company in offshore jurisdictions. Every tenth Russian company with revenues from 1 to 30 billion rubles has parent or profit center consolidation, where $40 \%$ of their shares are stored. In the field of small businesses, $5-15 \%$ of companies are owned by the offshore companies (See Figure 6).

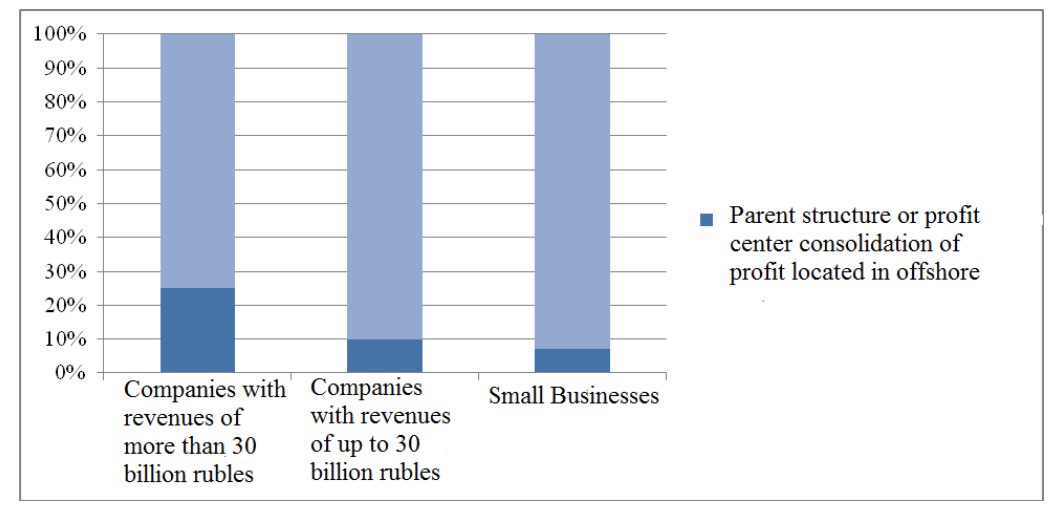

Figure 6. Offshore structures share in Russian companies

Russian President Vladimir Putin in his annual address to the Federal Assembly of the Russian Federation of December 12, 2013 pointed out that a fifth of Russian exports and half of the investment in other countries went through the offshore (Message of the President of the Russian Federation, 2013). Despite the marked beginning of the deoffshorization course, capital flow continues from the country. According to the Ministry of Economic Development and Trade, for the beginning of 2014, \$35 billion were cut out Russia (Budget Message of the President of the Russian Federation, 2014).

In order to better understand the scale of what is happening, we turn to the statistics, including international one. According to the Global Financial Integrity (GFI) American international Research Organization, Russia is one of the leaders in terms of exported capital in absolute terms, behind only China. According to Illicit Financial Flows from Developing Countries 2002-2011 Research undertaken by the organization (Illicit Financial Flows from Developing Countries 2002-2011) (Kar \& LeBlanc, 2013), more than $\$ 880$ billion was exported from Russia for the period. These data were obtained on the basis of the errors and omissions article, balance of payments, as well as differences in the foreign trade statistics. In another Russia: Illicit Financial Flows and the Underground Economy Study (Russia: Illicit Financial Flows and the Underground Economy) (Kar \& Freitas, 2013), experts of the organization indicate that the main method of illegal withdrawal of money is the use of the European and offshore subsidiaries, through which funds are withdrawn by the Russian commercial entities under the guise of export and import operations.

According to the Federal Customs Service of Russia, for the period of 2010-2012, the volume of unreturned funds from foreign trade activity exceeded 1.3 trillion rubles (FCS of Russia, 2013).

According to the Central Bank of Russia (http://www.cbr.ru), for the period from 2005 to 2014, \$438 billion were cut off Russia. This figure exceeds the amount of the state budget in 2014. 
These figures testify the threatening consequences of this phenomenon for the Russian economy. This conclusion is supported by domestic experts, who believe that the offshorization process is a threat to national security of the Russian economy, as it generates negative processes that prevent it from effectively development (Ageeva, Pinskaya, \& Bauer, 2014, pp. 3-8).

\subsubsection{Russian Offshore Regulation Rules Retrospective Review}

Russia's first attempts to regulate the offshore companies were taken by the Central Bank of Russia, which in 1999 introduced a system of currency regulation in the offshore zones (Decree of the Bank of Russia, 1999), it also established the list of the offshore zones (Appendix 1 to the Decree of the Bank of Russia, 2003), and established a procedure for reservation of funds for the operation of credit institutions with offshore residents (Decree of the Bank of Russia, 2003). The first definition of a resident of an offshore zone appeared in the Decree of the Central Bank (Decree of the Bank of Russia, 2005). The Bank of Russia defined the offshore as "the territories offering preferential tax regime and /or not requiring the disclosure and provision of information on financial operations (offshore zones)" (Decree of the Bank of Russia N 629-U, 1999). A similar definition was reproduced in the Tax Code of the Russian Federation, where the offshore zones are understood as the states and territories providing preferential tax regime and/or do not require disclosure and provision of information on financial transactions, and appropriate list of them was approved by the Ministry of Finance of the Russian Federation. A number of steps have been taken in connection with the entry of the Russian Federation in the FATF, fulfilling the recommendations, Russia began a policy of tightening of banking legislation and control of increasing transparency of corporate structures, became a member of the international tax information exchange. In 1999 Russia has signed and ratified the Strasbourg Convention of the Council of Europe dated 8 November 1990 "On Laundering, Search, Seizure and Confiscation of the Proceeds from Crime" in 2001, participation in which has expanded opportunities for cooperation with the European countries in the fight against the laundering of proceeds of crime.

The need for changes in state tax policy of Russia in relation to offshore arose a long time ago and was denoted by many economists and lawyers. At the highest level, the deoffshorization idea was first performed by the President of the Russian Federation Vladimir Putin in May 25, 2009. Finally, the turning point was the message of the President of the Russian Federation to the Federal Assembly of the Russian Federation in December 12, 2013, after which the deoffshorization process moved into the active stage.

Adopted at the end of 2014 Russia's deoffshorization regulations are an attempt to implement a systematic approach to solving the problem, which is absolutely justified based on the complexity of the offshorization phenomenon. There are the following interrelated elements of the deoffshorization: the first is making a significant amount of changes to the Tax Code of the Russian Federation, which entered into force on 1 January 2015 by the Federal Law dated 24 November 2014 No. 376-FZ "On Amendments to Parts 1 and 2 of the Tax Code of the Russian Federation (as regards income and profits taxation of controlled foreign companies)" (Federal Law No. 376-FZ) (hereinafter - the Law); the second is the accession to international practice for the tax information exchange; the third is the formulation and solution of the issue of capital amnesty. Let us consider them in particular.

\subsubsection{Controlled Foreign Companies: Integration in the Russian Tax System}

The main purpose of the enactment is to counter the erosion of the tax base, the use of offshore companies in order to minimize taxation, as well as the disclosure of beneficiaries. At the stage of the law preparation, it repeatedly undergone changes caused by wide discussion among scientists and businessmen. The basic concepts of deoffshorization in Russia, introduced by the Law, are the rules of the controlled foreign companies (hereinafter - CFC), the concept of the beneficial owner, the rules of the tax residence. Let us refer to the key points of these innovations. The following principle are laid as the basis of the Russian CFC regulations: as the Russian tax resident has the opportunity to postpone the payment of tax on dividends in Russia for an indefinite period due to the retained earnings of foreign companies controlled by him/her, the CFC rules are aimed at recognition of such profits distributed for tax purposes at the end of a certain period from the time when foreign companies have a profit. The concept of "controlled foreign company" was introduced, which is an organization or entity without legal personality, which is not tax resident of the Russian Federation, but is controlled by such resident. Controlling persons are citizens who own more than $50 \%$ in the capital of a foreign company, as well as citizens who, together with their spouses and minor children own more than $10 \%$ in the capital of the foreign company, provided that the foreign company itself is more than half owned by the Russian tax residents. With respect to legal entities, a similar rule operates. The threshold is now set at $50 \%$; it will be reduced to $25 \%$ in 2016. The profit of some CFC is exempt from taxation. The controlling persons shall be obliged to inform the 
tax authorities about their participation in the capital of the controlled companies, to declare and confirm their retained earnings. The minimum amount of income subject to declaration is set: 50 million rubles in 2015, 30 million rubles in 2016, 10 million rubles in 2017. Failure to report about the CFC, non-payment or underpayment of taxes subject to a fine due to the fact that, in determining the tax base CFC profits have not been considered. In addition to this action, the criminal liability is applied for the tax evasion.

\subsubsection{Beneficial Income Owner and Tax Residency Concept Development}

The second key innovation of the law is the concept of the beneficial owner. According to this concept, reduced tax rates set forth in the agreements on avoidance of double taxation, apply only to persons having the beneficial owner of such income, shall apply to persons who have the right to determine the economic fate of the income they receive, in particular, do not carry out mediate functions. To assess these competences, those functions are important that are performed by the person, his/her power, risks and the fact of the income transfer (fully or partially) to third parties. However, the Tax Code does not contain a specific checking procedure for the beneficial ownership, and if the beneficial ownership is not subsequently confirmed, it entails risks for the Russian tax agents, who will have to pay fines and pay extra tax at their expense. If the tax agent has been known the person who actually has the right of such income, it is possible to apply the agreement on avoidance of double taxation with the country of residence of the said person.

The third significant change of the Tax Code was the revision of the rules of legal persons' residence. Now, the foreign organizations, which are controlled from Russia, may be recognized as tax residents of the Russian Federation, as a result, their worldwide income is subject to tax in Russia. Key criteria for determining of actual management location are the following:

- The meetings of the governing body of the organization are carried out mainly in the territory of Russia;

- A governing control is performed mainly from Russia;

- The main officials mainly carry out their activities in respect of this organization in Russia.

There are also additional criteria applied in case of failure of basic criteria. If a foreign organization operating in Russia through a separate division alone pleads itself as a tax resident of the Russian Federation, it will not be recognized as the CFC.

\subsubsection{Introduction of Russia's New Foreign Countries' Tax Authorities}

Significant changes in the information exchange are the second element of the Russian economy deoffshorization. A. G. Siluanov, Russian Minister of Finance told about their need: "Now, within the OECD, a two-year plan was prepared, which provides the information exchange in an automatic mode as well, not on request, as it is today among the various jurisdictions. We have to move in that direction" (Siluanov, 2014).

To extend the capabilities of the Federal Tax Service to obtain information from the tax authorities of foreign states, in August 14, 2014, the Russian Government approved the Model Agreement between the Government of the Russian Federation and foreign governments for the information exchange on tax matters (RF Government Resolution N 805, 2014). The agreement was designed in accordance with the OECD standards. Under the terms of this standard agreement, the information exchange shall be applied to any taxes, and not only those for which the international tax treaties were signed. The obligation of the requested state to provide information is limited to the information held by public authorities of that state and which is in the possession or control of persons who are under the jurisdiction of the requested state.

In November, 2014 Russia ratified (Federal Law N 325-FZ, 2014) Joint Convention of the Council of Europe and the OECD on Mutual Administrative Assistance in Tax Matters signed in 2011 (Convention ETS N 127, 1998). Under the convention, countries will assist each other in exchanging information, carrying out simultaneous tax audits, collection of tax arrears and interim measures. However, Russia excluded state and local taxes from the list of tax in respect of which the states may refuse administrative assistance.

The offshore capital amnesty is the third element of the Russian economy deoffshorization. A draft of the Federal Law prepared by the Government of the Russian Federation does not require residents to return capital in the Russian national jurisdiction, it provides 0 tax rate on declared capital, and provides exemption of administrative and criminal liability (in consultation with the FATF). Thus, the amnesty would not be fiscal in Russia, and is aimed at taxation of the "legalized" funds in future periods. 


\section{Results}

\subsection{Suggestions to Improve the Russian CFC Rules}

Further improvement of the Russian tax legislation, regulating the use of low-tax jurisdictions in the international tax planning is appropriate taking into account the recommendations of the OECD and the international best practices in this field.

Comparative analysis of the recommendations of the OECD and the current Russian tax legislation regarding the CFC has allowed us to conclude that the overall Russian current CFC rules comply with the recommended position by the OECD (OECD, 2015).

The Tax Code is set a threshold in relation to the CFC, whose permanent residence is the state, which has an international treaty on taxation and exchanges information with Russia. Taking into account exchange information instruments and new Russian rules for the beneficiary owner currently available in the arsenal of tax bodies, such companies do not seem highly risky in terms of erosion of the tax base and the withdrawal of profits from taxation.

In this regard, in the medium term, taking into account the practice of the new CFC provisions of the Tax Code, we believe it is expedient further to analyze and clarify the validity of the established threshold of 75 percent of Russia's average tax rate for income, so that the costs of administration and compliance of the CFC do not exceed paid amount of tax in respect of the CFC.

Since January 1, 2016, the Russian law sets $25 \%$ as a person or entity's interest in a foreign organization for the getting status of the CFC. Obviously, this approach shall be rethought, taking into account the practice of the Russian CFC rules in the medium term, with a view to ensuring a balance between the taxation of foreign income and maintaining the competitiveness of the Russian residents, as well as the CFC role as a preventive measure, etc. The solution of this problem would contribute to the establishment of a 50 percent share of supervision

The provisions of the Tax Codes are advisable to be clarified regarding the rules of profit allocation to the respective CFC owner. The amount of profit attributable to each owner or a controlling person shall be calculated with respect to two parameters, such as the share of their property and the period of ownership or control. Currently, in Russia, only one parameter is used, that is the share of the property.

\subsection{Recommendations to Improve the Russian Residence Criteria for Organizations}

As a significant lack of the Tax Code in the part of the tax residence distribution, we should mention the possibility of recognizing a person as a tax resident of Russia without the basic residence criteria on the basis of additional (component) features, which include, in particular, the maintenance of accounting or administrative account in Russia, Russia's record keeping, etc. This approach distorts the method of tax residency in international taxation, since there is no evidence of close economic ties with the state, where a person can be recognized as a resident. In addition, the current formulation of the Tax Code concerning the exclusion of resident status in Russia for the holding companies, may significantly limit range of companies applying for the exception. Also, the application of this exception needs the continuous monitoring to be carried out on compliance of the holding company to the criteria provided by the Tax Code (in particular, "activity" tests of the subsidiaries, the holding company's income composition).

In this regard, it is appropriate to specify Par. 5 of Sec. 246.2 of the Tax Code regarding the use of the complementarity of the additional criteria:

- Or in the case when one of the first two main criteria is implemented;

- Or if the first two main criteria are not implemented, but the third main criterion is implemented subject to the governing administration.

\subsection{Recommendations for the Russian Concept of Beneficiary Owner}

According to the Russian professional community, the new rules of the Tax Code in regarding to the beneficiary owner are not backed by the necessary implementation mechanisms, as follows: it is not clear what documents are necessary and sufficient to confirm the actual right to the income of a foreign person, by which methods and means the Russian tax agent shall conduct such an investigation.

Based on the logic of the Tax Code, the Russian organization bears the burden of proving the status of the beneficiary owner. The absence in the Tax Code of a specific checking order of the beneficiary owner status 
entails a great risk to the Russian tax agents, who will have to pay fines and to pay extra amount of tax on foreign recipient's income at their own expense, if the beneficiary owner status is not subsequently confirmed.

In this regard, in cases where the tax agent has reason to believe that he has insufficient information, the issue of confirming the beneficiary owner status is offered to cut off the follow-up check by the tax authorities with responsibility measures to the Russian tax agents and put it in the field of preliminary agreements between the Russian tax agent and tax authority. This approach is more effective because it provides simultaneous use of various mechanisms to confirm the beneficiary owner status, including those available for the tax authority (including the information exchange with the tax authorities of foreign countries). The conclusion of a preliminary agreement with the tax authority on the beneficiary owner status will significantly reduce the administrative compliance costs of tax relations participants, minimize tax risks and ensure the maintenance of the competitiveness of the Russian tax agents.

\section{Discussion}

Well-known Russian lawyers D. Vinnitsky, A. Savitsky critically noted that Russian legislation is quite loyal to offshore companies and deals with them if they do not contain evidence of serious crimes (Vinnitsky \& Savitsky, 2013). D. M. Shchekin also rightly pointed out that the idea of the deoffshorization needs legislative regulation, though the Russian courts have long formed the approach of "infiltration under the corporate veil" for tax purposes, which became a powerful factor in regulation of tax relations (Shchekin, 2013). The Russian legislation has been criticized for inadequate rules on the organization residence by its place of establishment, the absence of domestic mechanisms for applying the concept of the beneficiary owner. L. V. Polezharova cited the US law as a sample of the well-designed CFC rules (Polezharova, 2011, pp. 83-96). M. A. Eskindarov also noted the need to improve the Russian legislation for deoffshorization (Eskindarov, 2012).

B. Bruk, V. Zaripov point out poor drafting of the new provisions of the Tax Code, poorly developed conceptual apparatus, the presence of a large number of evaluative definitions that may cause difficulties in interpretation and application of the rules, so their administration becomes very cumbersome (Bruk \& Zaripov, 2014).

L. Polezharova emphasizes the importance of effective mechanisms for international information exchange for the effective application of the CFC rules.

L. I. Goncharenko indicates the urgency of measures to stimulate the return of capital from offshore, as well as the CFC administrative measures as one of the areas of improvement of the Russian tax legislation (Goncharenko, 2014, p. 28).

According to R. I. Ahmetshin, T. A. Pavlyukova, it is also necessary to correct the new Russian tax residency rules, referring to the clear wording of the basic and complementary characteristics, the rejection of evaluation, excluding the possibility of getting Russian residency on the basis of additional features in the absence of the basic ones (Ahmetshin \& Pavlyukova, 2014).

Currently, experts debate whether the taken deoffshorization actions will result to return the capital to Russia. A. G. Siluanov noted that "the measures proposed by the President, according to preliminary estimates, will bring tens of billions of rubles to the budget" (Ministry of Finance, 2013). However, some experts do not believe that the introduction of the new rules will lead to a significant increase in tax revenues to the Russian budget.

The scientific literature supports the usefulness of the OECD recommendations for improving the tax legislation of Russia. V. P. Bauer, M. R. Pinskaya, E. S. Ageeva note that the OECD documents allow effectively unify the requirements on the Russian business deoffshorization (Bauer, Pinskaya, \& Ageeva, 2014, pp. 50-66). M. A. Kotliarov and I. N. Rykova indicate that the OECD BEPS plan contains approaches and methodological principles that can be used for improving the Russian tax legislation (Kotliarov \& Rykova, 2014, pp. 47-54).

As a further measure of the deoffshorization, scientists name the improvement of the business environment. I. V. Filatova (2014), A.N. Sukharenko (2014) criticize poor investment climate in Russia, the underdevelopment of the stock market and the current legislation. However, an outstanding Russian scientist S. Glazyev rightly notes that no normal tax system is able to compete with the offshore, and it is useless to try to achieve such result (Glazyev, 2014).

\section{Conclusion}

As can be seen from the above analysis, the Russian companies have developed advanced mechanisms of the international tax planning, based primarily on the use of low-tax or tax-free jurisdictions. At the same time, the Russian Federation actually did not have mechanisms to prevent the use of offshore companies for a long time. In 2014, relevant amendments were made to the law, and now we can say that Russia has entered a new phase of 
regulation of relations in this area. There are the following tax elements of the Russian economy deoffshorization: significant changes to the Tax Code of the Russian Federation; improving practices for the exchange of tax information, the planned offshore capital amnesty. The experts still disagree on the effectiveness of the measures taken, some large businesses, mainly for reasons of political allegiance, begin the return of capital to Russia. The new Russian rules on the controlled foreign companies, the beneficial owner and tax residents are in many ways imperfect, were taken hastily, and are not backed by the necessary implementation mechanisms. We have to expect that in the near future these rules will be the subject of many taxpayers controversy with the Russian tax authorities, and subject of the mutual agreement procedures regarding resident status in the framework of international agreements on avoidance of double taxation. The Institute of the international tax planning in connection with the introduction of the considered deoffshorization methods will not wither away but will get slightly different development trends and outlines due to the taken measures. At the same time, improving the rules on the basis of the analysis of law enforcement practice, of course, is an incentive for further scientific understanding of their development prospects and the continuation of scientific research in this area.

\section{References}

Ageeva, E., Pinskaya, M., \& Bauer, V. (2014). The economic security of offshore business: Tax optimization aspects. Business Security, 2, 3-8.

Akhmetshin, R., \& Pavlyukova T. (2014, October 10). Taxation of international organizations: Comments to Bill of the Russian Ministry of Finance, or what does the coming year prepare? Nalogoved.

Babanin, V., \& Voronina, N. (2006). Organization of tax planning in the Russian companies. Financial management, 1 .

Bank of Russia on February 12, 1999 No. 500-V "On strengthening foreign exchange controls by the authorized banks of the lawfulness of the foreign exchange operations exercise by their clients and on the procedure for applying sanctions to authorized banks for violation of currency legislation". (1999, February 24). Bulletin of the Bank of Russia, 13.

Bauer, V., Pinskaya, M., \& Ageeva, E. (2014). Russian Economy Deoffshorization in the system of combating with money laundering and terrorist financing. National interests: priorities and safety, 32(269), 50-66.

Beskarovayny, E. (n. d.). What is international tax planning. Classification of territories with preferential tax treatment. Information Channel Subscribe. Russian Federation.

Bruk, B., \& Zaripov, B. (2014). Law On Deoffshorization. Law, 12.

Budget Message of the President of the Russian Federation on Budget Policy in 2014-2016. (n. d.). Retrieved May 19, 2015, from http://kremlin.ru/acts/18332

Decree of the Bank of Russia on Monday, August 23, 1999 No. 629-V "On amendments and additions to the Decree of the Bank of Russia "On strengthening foreign exchange controls by the authorized banks of the lawfulness of the foreign exchange operations exercise by their clients and on the procedure for applying sanctions to authorized banks for violation of currency legislation" February 12, 1999 N 500-V. (1999, August 25). Bulletin of the Bank of Russia, 54.

Eskindarov, M. (2012, December 17). If the offshores are useful for economy. Itogi, 51(862). Retrieved May 28, 2015, from http://www.itogi.ru/business/2012/51/185201.html

FCS of Russia is effectively carrying out currency control in accordance with the assigned functions. (2013, February 15). Official website of the Federal Customs Service of Russia (the FCS of Russia). Retrieved May 28, 2015, from http://www.customs.ru/index.php?catid=40:2011-01-24-15-02-45\&id=17095:2013-02-1506-07-15\&Itemid $=1835 \&$ option $=$ com_content\&view $=$ article

Federal Law of November 24, 2014 No. 376-FZ "On Amendments to Parts One and Two of the Tax Code of the Russian Federation (profit taxing of controlled foreign companies and incomes of foreign organizations)". (2014, November 28). The Russian newspaper, 272.

Federal Law of November 4, 2014 No. 325-FZ "On ratification of the Convention on Mutual Administrative Assistance in tax matters". (2014, November 7). The Russian newspaper, 254.

Filatova, I. (2014). Economy offshorization influence on the national security of Russia. Immigration Law, 3.

Glazyev, S. (2014). Russian Economy Deoffshorization. Ways and measures. Moscow.

Goncharenko, L. (2014). On the question of tax incentives. Innovative Economic development, 6(23), 28. 
Kar, D., \& LeBlanc, B. (2013, December). Global Financial Integrity. Illicit Financial Flows from Developing Countries: 2002-2011. Retrieved May 28, 2015, from http://gfintegrity.org/wp-content/uploads/2014/05/ Illicit_Financial_Flows_from_Developing_Countries_2002-2011-HighRes.pdf

Kar, D., \& LeBlanc, B. (2013, February). Global Financial Integrity. Russia: Illicit Financial Flows and the Underground Economy. Retrieved May 28, 2015, from http://www.gfintegrity.org/wp-content/uploads/ 2013/02/Russia_Illicit_Financial_Flows_and_the_Role_of_the_Underground_Economy-HighRes.pdf

Kotliarov, M., \& Rykova, I. (2014). Opposition to the transfer of the tax base in low-tax jurisdictions: the OECD experience and priorities for Russia. Research Institute of Finance. Financial magazine, 4, 47-54.

Lipatova, I. (2011). International Tax Planning Mechanisms: Application theory and practice. International accounting, 37.

Message from Vladimir Putin, the President of the Russian Federation, to the Federal Assembly of the Russian Federation. (2013). Russian Newspaper. Retrieved May 28, 2015, from http://www.rg.ru/2013/12/12/ poslanie.html

Net capital import/export by the private sector in 2005-2014's. (n. d.). Official website of the Bank of Russia. Retrieved May 28, 2015, from http://www.cbr.ru/statistics/print.aspx?file=credit_statistics/capital_new. htm\&pid=svs\&sid=itm_18710

Obukhova, E., \& Ogorodnikov, E. (2013). It is time to return from the islands. Expert. Retrieved May 28, 2015, from http://expert.ru/expert/2013/04/pora-vozvraschatsya-s-ostrovov/

OECD. Addressing Base Erosion and Profit Shifting. (2013, February). Paris: OECD Publishing.

OECD. Public Discussion Draft BEPS ACTION 3: Strengthening CFC Rules. (2015). Retrieved May 28, 2015, from http://www.oecd.org/ctp/aggressive/discussion-draft-beps-action-3-strengthening-CFC-rules.pdf

Polezharova, L. (2011). The concept of the actual income recipient in international tax relations. Research Institute of Finance. Financial magazine, 4, 83-96.

Polezharova, L. (2014). Russian Economy Deoffshorization. Economy. Taxes. Law, 2, 100-105.

Resolution of the Government of the Russian Federation No. 805 "On the conclusion of agreements on the information exchange on tax matters" (2014, August 14). Meeting of the legislation of the Russian Federation.

Shchekin, D. (2013). Anti-offshore measures in the Russian tax law: Prospects of judicial practice. Law, 4.

Siluanov, A. (2013, December 12). Ministry of Finance: Deoffshorization measures will bring tens of billions of rubles to the budget. Russian news agency TASS. Retrieved May 28, 2015, from http://tass.ru/eko nomika/829551

Siluanov, A. (2014, February 25). The fight against offshore demands revision of double taxation agreements in Russia. Prime Business News Agency. Retrieved May 28, 2015, from http://www.1prime.ru/Politics/20140 225/778907820.html

Sukharenko, A. (2014). International cooperation as a key factor in the fight against tax evasion. Taxes, 5.

Tax Code of the Russian Federation. Part I and II (p. 630). (2014). Moscow: Prospect. Knorus.

Vinnitsky, D., \& Savitsky, A. (2013). The Russian legal system and problems of businesses and structuring of transactions involving low tax jurisdictions. The Law, 4.

\section{Copyrights}

Copyright for this article is retained by the author(s), with first publication rights granted to the journal.

This is an open-access article distributed under the terms and conditions of the Creative Commons Attribution license (http://creativecommons.org/licenses/by/3.0/). 